UDC 81

DOI https://doi.org/10.32838/2710-4656/2021.1-2/18

Zeynalov Eldar Atamali

Azerbaijan State Marine Academy

\title{
MANIPULATION IN BRITISH POLITICAL DISCOURSE (BASED ON NATIONAL AND CULTURAL VALUES)
}

The article discusses the use of national and cultural values as a means of manipulation by political leaders in their speeches in order to achieve the goals set in the British political discourse. The main goal of political leaders is to influence or maintain political power by influencing the minds of recipients and attracting them to their side. In this regard, manipulation, and especially the means of manipulation, is of great importance in political discourse. It is also noteworthy that British political leaders use tools of manipulation based on national and cultural values in British political discourse. British values are firmly rooted in the country's historical traditions. These values are protected by laws and traditions. Every member of British society unequivocally respects and protects these values and traditions. Concepts such as the democratic principles inherent in the public consciousness, the rule of law, individual freedom, tolerance of different denominations and active participation in public life are of vital importance to the British, and especially to the English. Because in the British political discourse, national and cultural values are closely linked with the English mentality and identity. Since the concept of values is specific to each community, they can be used in different forms and for different purposes. Given that the British are more conservative as a nation, it is clearer how important national-moral and cultural values are to them. In terms of semantic meaning, values can belong to different areas. Since national-moral and cultural values are of a collective nature, they can be considered as a ready-made means of "psychological influence". British national and cultural values are a manifestation of the British public consciousness and are based on the country's historical traditions. The use of national and cultural values, which are deeply rooted in English public opinion and memory, as a means of manipulation is interesting, which are illustrated in the article with examples.

Key words: political discourse, British political discourse, national-cultural values, manipulation, means of speech, political leader, political power.

Political discourse means "any form of speech, subject of speech, addressee or anything of this nature" that belongs to the field of politics from a functional point of view [6, p. 34]. The essence of political discourse is the struggle for power, and in their speeches, political leaders use a variety of linguistic and stylistic means and a variety of rhetorical styles to convey to the listener, to influence his consciousness.

This article focuses on how and in what form political leaders use national and cultural values in their speeches as a means of manipulation them in order to achieve the goals set in the British political discourse.

The point is that in the political discourse of the United Kingdom and the United States, the two largest English-speaking countries in the world, the way of thinking of the people living in those countries is very important. And we can note that this way of thinking is unique to the bearers of AngloAmerican political culture, which has a special place among the world's political cultures. Although they speak the same language, each of these countries has its own national political discourse. In addition to the general features of this political discourse, there are also mental features that belong to each of them separately. This is due to their linguocultural way of thinking. In general, when studying the political discourse of Great Britain and America, it can be concluded that the only thing that "distinguishes" the two English-speaking peoples can be "concepts rooted in the mental world of people and considered the core of culture" [3, p. 62].

The concept of national and cultural values is equally reflected in one way or another in British and American political discourse. Even in terms of the semantic meaning they express, they do not differ, except for some concepts. In every culture there are important cultural elements called "basic concepts". The following are the most common concepts in the collection of political values that have emerged in the speeches of British politicians and are frequently developed: home, history, compassion, privacy, creativity, common sense, fairness, democracy, freedom, tolerance, individual freedom, equality, liberty, decency, justice and, etc. 
In his speech on immigration in Staffordshire in 2014, Cameron's emphasis on these values, national and cultural concepts, shows how British politicians are connected to the English mentality and English identity. They try to make the most of this sensitivity when speaking in front of their audience: "When I think about what makes me proud to be British, yes, it's our history, our values, our creativity, our compassion. But there is something else too. I am extremely proud that together we have built a successful, multi racial democracy. A country where, in 1 or 2 generations, people can come with nothing, and rise as high as their talent allows. A country whose success has been founded not on building separate futures, but rather on coming together to build a common home" [15].

Russian linguist Y.I. Sheygal notes that in political discourse, since political values are of a collective nature, there can be no question of "one person's position". He then refers to the book by the American political scientist and scholar M.J. Edelman (Murray Jacob Edelman: The Symbolic Uses of Politics-1964, 115 ) and continuing his opinion writes that "in political discourse it is important not only accuracy, but also the generality of assessments of public interests" [7, p. 69].

Speaking of British values, it should be noted that they are firmly rooted in the country's historical traditions. These values are protected by laws, traditions and expectations. Every member of British society must unequivocally respect and preserve those values and traditions. According to British values and norms of life, concepts such as extremism and intolerance have no place in British society. The concepts that have been passed down from generation to generation as fundamental values in the UK are: 1.democracy; 2.the rule of law; 3.individual liberty; 4.tolerance of those with different faiths and beliefs; (participation in community life) [11].

An analysis of the speeches of British politicians and political leaders shows that the concept of national and cultural values in the country's political discourse is closely linked with the English mentality and identity. British politicians also take this factor into account in their public speeches and dig into history to create an effect on the listener's thinking, conveying to them the paths and difficulties of their ancestors in verbal and non-verbal ways (showing chronicles of historical events, pictures, etc.). Consider an example. Commenting on Scotland's secession from the United Kingdom in February 2014, David Cameron said: "Over 3 centuries we have lived together, worked together and frankly we've got together: getting married, having children, moving back and forward across our borders. Such is the fusion of our bloodlines that my surname goes back to the West Highlands and, by the way, I am as proud of my Scottish heritage as I am of my English or my Welsh heritage. The name Cameron might mean 'crooked nose', but the clan motto is 'let us unite', and that is exactly what our islands and our nations have done [8, p. 32].

Apparently, Cameron is digging into history, trying to do his best to preserve the unity and integrity of Great Britain. This tradition is reflected in the public speeches of all British politicians and continues to this day. Consider an example from Tony Blair's speech in 2000 entitled British Identity and Society: "Britain is stronger together, than separated apart. True Britishness lies in our values not unchanging institutions. Standing up for Britain means fighting for British values, ..." [10]. In this example, Blair calls on his listeners to take ownership of Britain's unity and integrity and to preserve the existing unity.

It is necessary to emphasize one issue. In the UK, the leaders of the two leading parties, the Conservative and Labor parties, have been advocating the values that their parties support in their political campaigns. However, both parties consider the values they support as national values and try to condemn the other side by referring to them in their speeches. Research shows that although parties prefer different values, they share a common point; these values are the values of the whole country. For example, in a 2014 article in the Daily Mail, Cameron stressed that all citizens of the country should have values such as equality and the rule of law. With this view, he sought to justify the weakening of British identity in the country, arguing that the weakening of values such as British identity had led to an increase in extremist sentiment within the country, especially among immigrants: "A failure to promote 'British values' in a muscular way is allowing extremism to grow in the UK. The values I'm talking about - a belief in freedom, tolerance of others, accepting personal and social responsibility, respecting and upholding the rule of law - are the things we should try to live by every day. To me they're as British as the Union flag, as football, as fish and chips" [14]

According to Cameron, not only immigrants in Britain, but also the British must respect and protect English national and cultural values. He argues that British values should be studied more deeply, especially in English schools, and that students should study historical documents, especially the "Magna Carta", adopted in 1215, which paved the way for the rule of law and parliamentary democracy in the country. 
The article focuses on the issue of British identity and emphasizes the importance of learning English for immigrants.

D.Cameron writes that without knowing English, it would be difficult to get used to British culture and English values, to get to their essence: "We are making sure new immigrants can speak English, because it will be more difficult for them to understand these values, and the history of our institutions, if they can't speak our language" [14].

Since British traditions and national-cultural values are very important for British society, British politicians attach great importance not only to manipulating this issue in the public consciousness, but also to the deeper study, promotion, protection and respect of these values in the country. Speaking on extremism and the scourge of extremism in Birmingham on July 20, 2015, Cameron reiterates the importance of integrating immigrants into British society, in this process the UK again emphasizes its traditions and values, reaffirms their importance in the construction of the British House. He says: "We are all British. We respect democracy and the rule of law. We believe in freedom of speech, freedom of the press, freedom of worship, equal rights regardless of race, sex, sexuality or faith. We believe in respecting different faiths but also expecting those faiths to support the British way of life. These are British values. And are underpinned by distinct British institutions. Our freedom comes from our Parliamentary democracy. The rule of law exists because of our independent judiciary. This is the home that we are building together" [13].

It is obvious that the unity in the country, the preservation of this unity is always the main line in the speeches of the country's leaders.

Political people use various means to manipulate public opinion. Along with the lexical and stylistic means of language, other means also play an important role here. The national-spiritual, cultural heritage, religious ceremonies and beliefs rooted in the memory of the people and passed down from generation to generation are, of course, considered to be such means. The interesting thing is that in the process of political communication, theinformation transmitted by the speakerto thelistener takes time to make an impact, or rather, the listener begins to "process" in his brain from the moment he receives the information delivered to him. He tries to find out how true or false the information is. The impact of information begins after the "processing" process. Politicians and political leaders understand this very well. Accurate and talented speakers try to use such means in their speeches in political campaigns that the listener does not need to "process" the information transmitted to them and accepts it as it is. Such tools, as we have noted, are concepts that are deeply rooted in the memory of the people and do not require "discussion and analysis". Usually, during this type of speech manipulation, the addressee (listener) is exposed in such a way that he perceives the information given to him as objective information. As the Russian linguist G.V.Pushkareva noted, "the manipulator always resorted to such covert means that people are deprived of the opportunity to receive information critically, to judge independently and to make decisions" [1, p. 90].

According to political experts, manipulation of public opinion in the modern world is one of the most effective mechanisms as a means of ensuring political stability in the country in general.

Theresa May, the leader of the Conservative Party from 2016 to 2019 and the Prime Minister of the United Kingdom (she was the Home Secretary of the United Kingdomin 2015(2010-2016)), said this in 2015 when she spoke about the need for the entire British public to come together to fight extremism: "Our definition of extremism is "the vocal or active opposition to fundamental British values, including democracy, the rule of law, individual liberty and the mutual respect and tolerance of different faiths and beliefs". To highlight the value of these values to the British, she again goes back in time, noting that these values were passed down from generation to generation, not just from the air:

"Because our values haven't just sprung out of nowhere. They have evolved over centuries in response to our political, cultural, religious andintellectual history. We believe in religious freedom because the alternative is conflict and bloodshed. We believe in democracy because the alternative leads to the arbitrary abuse of power. We believe in equality because the alternative is discrimination and suffering. We believe in our values because they are what make a successful society" [9].

As noted above, when analyzing the political speeches of British politicians, political leaders and Prime Ministers, one aspect is generally more prominent: maintaining and strengthening the unity of all the peoples of the United Kingdom. This is a problem that British politicians, political engineers and heads of state are aware of and constantly "control". Some researchers claim that the history of this problem dates back to 1707, when the British people and the British identity were formed. At that time, an official union act was signed between 
England and Scotland, and "it was agreed that the official name of the state created under this act would be Great Britain" [2, p. 77].

Prime Minister David Cameron uses a persuasive strategy to address patriotism in a referendum on Scottish independence in February 2014, raising patriotism to the level of social value: "And I passionately hope that my children will be able to teach their children the same; that the stamp on their passport is a mark of pride that together, these islands really do stand for something more than the sum of our parts, they stand for bigger ideals, nobler causes, greater values. Our great United Kingdom: brave, brilliant, buccaneering, generous, tolerant, proud - this is our country. And we built it together. Brick by brick: Scotland, England, Wales, Northern Ireland. Brick by brick" [12].

Political discourse is considered an important part of national culture. When we look at the linguistic landscape of the political world, we see the emergence of complex mental units (concept, stereotype, scenario, conceptual field, value, etc.) belonging to each nation in political communication and political discourse. When talking about national-moral and cultural values in political discourse, it is very important what level they occupy in the political consciousness of individuals, society and the people as a whole. Because when we say values, we mean things that "subjects of political activity (specific people, political movements, political parties and their representatives) consider very important for themselves and declare their readiness to fight for them" [5, p. 39].

Of course, national and cultural values are a broad concept. According to A.P.Chudinov, it is expedient to generalize the political values used for the purpose of manipulation in the following order:

1) higher values - man, mankind, humanity;

2) material values - natural resources, products of labor, tools and their reproduction necessary for the existence of mankind, humanity;

3) values related to social life - various social institutions created during the progressive development of mankind and social institutions necessary for the life of society: family, nation, class, state;

4) Moral life and cultural values-scientific knowledge, philosophical, moral, aesthetic and other ideas, ideas, norms, ideals designed to meet spiritual needs;

5) Political values - freedom, democracy, human rights, the rights of the nation, etc. [5, p. 39].

Since it is important for politicians to be in direct contact with their audience, it is important to work hard for the audience. Rather, success depends on how visionary, skilled, educated, and skillful speaker a politician is. There is no denying that national-spiritual and cultural features play an important role in creating an emotional, expressive effect in the British discourse.

As the Russian philologist N.V. Salnikova noted, "pragmatism in political communication is mainly characterized by high intensity, and the power of speech is the main goal of communication. This is primarily due to the expression in the speech of national and cultural values that determine the political course of the speaker. As nationalcultural values are the basic concepts of the people, they become an integral part of the national selfconsciousness by forming a unity of views and beliefs between a political person and the people" [4, p. 7].

Thus, the analysis of the political speeches of British politicians, political leaders and heads of state shows that maintaining unity in the country is the first task, and more emphasis is placed on manipulating this ideology. Since political leaders aim to come to power and maintain it as the main goal in political discourse in the pre-election and post-election periods, they prefer to be closer to the people, to dominate their thinking, to have their views, in short, to find their sensitive spots and have them follow him. Examples of British political discourse show that in the speeches of leaders, "British-British identity" should be seen more as a political value used for unity and equality. However, the frequent reference to the set of national, spiritual and cultural values that characterize British political discourse not only strengthens the people's views on language, culture and social closeness, but also strengthens their sense of national identity.

\section{References:}

1. Володенков С.В. Современная политическая коммуникация как инструмент манипулирования общественным сознанием. Вестн. Моск. Ун-та. Сер. 12. Политические науки. 2012. № 5.

2. Демидова Д.Г. Понятие национальной идентичности в политическом дискурсе Великобритании (на материале текстов публичных выступлений парламентариев-консерваторов в 2010-2016 годах). Социальные и гуманитарные знания. 2017. Том 3, № 1. С. 76-80.

3. Левенкова Е.Р. Контрастивный анализ национально-специфических концептов в институциональном политическом дискурсе Великобритании и США. Вестник Челябинского государственного университета. 2010. № 32(213). Филология. Искусствоведение. Вып. 48. С. 62-704. 
4. Сальникова Н.В.Национально-культурная риторикаполитического дискурса (на материалепубличных выступлений Р. Рейгана и М.С. Горбачева). Автореферат диссертации на соискание ученой степени.

5. Современная политическая коммуникация: Учебное пособие / Отв. Ред. А.П. Чудинов / Урал. гос. пед. ун-т. Екатеринбург, 2009. 292 с.

6. Шейгал Е.И. Семиотика политического дискурса. Волгоград, 2004.

7. Шейгал Е.И. Семиотика политического дискурса : дис....д-ра филол. наук. Волгоград, 2000. 326 с.

8. Understanding National Identity. By David McCrone, Frank Bechhofer, Cambridge University Press, 2015. United kingdom. 225 p.

9. A Stronger Britain, Built On Our Values, 23 March 2015 (Retrieved on May 24, 2020). URL : https://www.gov.uk/government/speeches/a-stronger-britain-built-on-our-values.

10. British İdentity and Society.Tony Blair's Britain speech, 28 Mar, 2000. (Retrieved on May 23, 2020). URL : https://www.theguardian.com/uk/2000/mar/28/britishidentity.tonyblair.

11. Chapter 1: The Values and Principles of the UK (Retrieved on May 24, 2020). URL : http://www.test4citizenship.com/chap1section1.

12. David Cameron - 2014, Speech on Scottish Independence. November 20, 2015 (Retrieved on May 24, 2020). URL : http://www.ukpol.co.uk/david-cameron-2014-speech-on-scottish-independence/.

13. David Cameron extremism speech: Read the transcript in full, 20 July 2015. Home Secretary: A New Partnership To Defeat Extremism. URL : https://www.independent.co.uk/news/uk/politics/david-cameronextremism-speech-read-the-transcript-in-full-10401948.html.

14. British values aren't optional, they're vital. That's why I will promote them in EVERY school... URL : https://www.dailymail.co.uk/debate/article-2658171/DAVID-CAMERON-British-values-arent-optionaltheyre-vital-Thats-I-promote-EVERY-school-As-row-rages-Trojan-Horse-takeover-classrooms-Prime-Minister-delivers-uncompromising-pledge.html (Retrieved on May 23, 2020).

15. JCB Staffordshire: Prime Minister's speech. November 28, 2014. (Retrieved on May 23, 2020) speech. URL : https://www.gov.uk/government/speeches/jcb-staffordshire-prime-ministers.

\section{Зейналов Ельдар Атамалі. МАНІПУЛЮВАННЯ НАЦІОАЛЬНИХ І КУЛЬТУРНИХ ЦІННОСТЕЙ У БРИТАНСЬКОМУ ПОЛІТИЧНОМУ ДИСКУРСІ}

У статті обговорюється використання національних та культурних иінностейякзасобу маніпуляцій політичнимилідерами у своїх виступах для досягнення цілей, встановлених у британському політичному дискурсі. Головною метою політичних лідерів є вплив або підтримка політичної влади, впливаючи на свідомість реципієнтів $і$ залучаючи їх на свій бік. У зв'язку із ичим маніпуляиія, а особливо засоби маніпулячії, мають велике значення в політичному дискурсі. Також варто відзначити, щ⿻о британські політичні лідери використовують інструменти маніпуляцій, заснованих на начіональних та культурних цінностях, у політичному дискурсі Великобританії. Британські цінності міџно вкорінені в історичних традииіях країни. Ці иінності захищені законами та традиціями. Кожен член британського суспільства однозначно поважає та захищає иџі иінності та традиџї. Такі поняття, як демократичні принципи, притаманні суспільній свідомості, верховенство права, свобода особистості, толерантність до різних конфесій та активна участь у суспільному житті мають життєво важливе значення для британців, особливо для англійщів. Оскільки в британському політичному дискурсі начіональні та культурні иінності тісно пов'язані з англійською ментальністю та ідентичністю. Оскільки поняття цінностей характерне для кожної спільноти, їх можна використовувати в різних формах та для різних иілей. Ураховуючи, щз англійці більш консервативні як нація, стає зрозумілішим, наскільки важливими для них є національно-моральні та культурні иінності. Із точки зору семантичного значення иінності можуть належати до різних областей. Оскільки національно-моральні та культурні цінності мають колективний характер, їх можна розглядати як готовий засіб «психологічного впливу». Британські національні та культурні иінності є проявом суспільної свідомості Великобританії та базуються на історичних традиціях країни. Цікавим є використання національних та культурних иүінностей, які глибоко вкорінені в англійській громадській думиі та пам'яті, як засобу маніпуляиії, що проілюстровано у статті на прикладах.

Ключові слова: політичний дискурс, британський політичний дискурс, наиіонально-культурні цінності, маніпуляція, засоби мови, політичний лідер, політична влада. 